\title{
ADULT READING AND MEANING MAKING IN A MUSEUM EXHIBITION ABOUT ANCIENT CHINA
}

\author{
Colette Dufresne-Tassé ${ }^{1}$ \\ Maîtrise en muséologie, Université de Montréal (Canada)
}

\begin{abstract}
Adults of the general public type who visit an exhibition whose subject is almost unknown to them attach great importance to reading the major texts (panels) of that exhibition. These texts provide them with the conceptual structure of the exhibition. They allow them to discover and appropriate the subject of the exhibition with very few mistakes. But they do not support its enrichment through personal contributions, for example in the form implications derived from reasoning. Why? This is the simple, but unexplored question in the museum context, that is studied here. ${ }^{2}$
\end{abstract}

Keywords: Adult visitors, reading, exhibition, meaning making.

\section{Introduction}

In a thematic temporary exhibition ${ }^{3}$, reading the texts that accompany the objects is a major activity. It is the main way to discover the meaning of each object and to understand the phenomenon presented, for example, an historical fact, the way of life of a cultural group, a natural phenomenon or the work of an artist (Hooper Greenhill, 1994 ; Merleau-Ponty and Ezrati, 2005; Poli, 2002; Ravelli, 2006; Serrel, $1996^{* 4}$ ). In other words, the production of meaning corresponds to an appropriation, i.e. a recreation by the visitor of the content of the exhibition, the abundance and characteristics of the production of meaning determining the breath of the visitor's recreation (Dufresne-Tassé, O'Neill, Sauvé and Marin, 2014).

Regarding the characteristics of the production of meaning, M.C. O'Neill of the École du Louvre and a group of her students ${ }^{5}$ observed several times six different orientations of this production, only one corresponding exactly to the recreation of the exhibition content. The orientations identified are as follows:

- Meaning is in line with what the curator is saying in the exhibition; it fits perfectly its content;

- It is beyond the content of the exhibition; it complements and enriches it;

- It constitutes a clear opposition to what the curator says in the exhibition;

- It is incomplete in the sense that it takes the form of a question or hypothesis;

- It is simply not true, because it contradicts generally accepted knowledge;

- It is completely foreign to the content of the exhibition.

\section{Context of data collection}

The present research was carried out in a large temporary thematic exhibition on ancient China offered in Quebec City by the Musée de la civilisation. This exhibition was chosen because its subject was quasi unknown to the Quebec public and so, we expected, would lead to ample reading and an opportunity to study it.

\footnotetext{
${ }^{1}$ Have also contributed to this research: Marie-Clarté O'Neill from the École du Louvre, and Anne-Marie Émond from the Université de Montréal.

2 This research has been funded by the Social Sciences and Humanities Research Council of Canada (SSHRC), by the Fonds pour la formation de chercheurs et l'aide à la recherche, as well as by the Fonds Québécois de la recherche sur la société et la culture (FQRSC) of the Province of Quebec Government. It also received some logistic support from the Université de Montréal.

${ }^{3}$ Temporary exhibitions are usually thematic, i.e. they present their content according to a general theme divided in a certain number of sub-themes.

${ }^{4}$ As the subject matter has been treated in many other publications, references marked with an $(*)$ are only examples.

5 See: Adjadj, 2004 ; Baudon, 2002 ; Cabille, 2001 ; Hely, 2001 ; Jeannoutot, 2003 ; Krummenaker, 2001; Letellier, 2003 ; Pralus, 2004 ; Quantin, 2002 ; Rey-Jouvin, C. 2002 ; Rondet, 2001 ; Vicedo, 2003
} 


\section{Sample}

A group of 30 visitors, from 28 to 64 years of age (mean 34.8), including the same proportion of men and women of three levels of schooling (baccalaureate, less than a baccalaureate, and more than a baccalaureate), and low visiting habits (once or twice a year); in other words, a sample of "the general public" type.

\section{Data on the reading of the 30 visitors of the sample}

The group of 30 visitors read 4,532 times, with an average per visitor of 161, and a standard deviation of 68.29. The main texts of the exhibition, namely its panels (introductory texts and texts presenting each of its parts) and the labels attached to each object, were read as follows:

- Panels: Average readings: 20.52 per visitor, with a standard deviation of 11.95; this represents the reading of $81.58 \%$ of all the panels;

- Labels: Average readings: 39.76 per visitor, with a standard deviation of 24.60; this represents the reading of $41.67 \%$ of all the labels.

According to what is known about reading museum texts (Black, G. 2005; Daignault, 2011; Serell, $\left.1996^{*}\right)$, one could consider that the reading rate of panels is particularly high, while that of labels is rather low. It can therefore be assumed that the novelty of the exhibition's subject matter captured the visitors' attention more than the exoticism of the objects presented, and that visitors preferred to discover the exhibition's content based on the general information it presented rather than on the information attached to each object.

\section{Means of collecting information on meaning production}

As it was not possible to use a standardized questionnaire (there was no relevant one), and because a post-visit interview would have led to invalid data (due to many factors like memory overload), information from each visitor was obtained through the Thinking Aloud Technique (Ericcson and Simon, 1993). A version that we adapted and validated for the museum situation was used. It consists in asking a visitor who is arriving at the museum to do her/his visit as she/he wishes, saying aloud what comes to her/his mind without bothering remembering or justifying it (Dufresne-Tassé and al., 1998a, 1998b).

The visitor voicing her/his experience as it unfolds (Hirtle, 2013), she/he reveals what she/he is thinking, imagining or feeling, i.e. her/his production of meaning while observing or reading. We called this visitor's oral production "a discourse". We tape registered and then computerized it, so it could be studied in its written form.

\section{Hypotheses}

The visitor's reading behaviour described above, combined with the six outcomes of the meaning production identified by O'Neill and her students suggested the following hypotheses.

Correspondence of meaning production with exhibition content (70\%)

1. The majority (50\% or more) of the production of meaning is in line with what the curator is saying in the exhibition, and represents a recreation for the visitor;

2. The creation of meaning that enriches the content of the exhibition is relatively frequent (about $20 \%$ ) because by reading the panels, the visitor has a representation that is both precise and articulated and can thus use her/his imagination or her/his ability to reason and produce implications.

Uncertainty of meaning production in relation to exhibition content (15\%)

3. Given the precise and structured representation that the visitor can develop of the exhibition's content, its production of meaning in the form of questions or hypotheses should be very limited. However, its relatively low consultation (less than one label out of two) is likely to generate uncertainties and doubts that would lead to questions or hypotheses.

Divergence of meaning production from exhibition content (10\%)

4. The production of meaning that is in direct opposition to the curator's thought should be relatively rare (about 5\%), because it is difficult for a visitor to oppose an articulated discourse that deals with a subject with which she/he is very little or not at all familiar.

5. As for the creation of meaning that leads to notorious falsehoods, it should be relatively rare (5\%), because, as we have seen, the texts of the panels are precise and articulated, so they safely guide the visitor's production of meaning. 


\section{Escape of meaning production from the content of the exhibition (5\%)}

6. Finally, for similar reasons, a production of meaning foreign to the content of the exhibition should be very rare (5\% or less). Indeed, guided by a precise and articulated discourse about a subject matter that she/he has chosen to discover, the visitor should not be tempted to think of something else.

\section{Results}

Correspondence of the production of meaning coming from the visitors who participated in this research with the exhibition content is less strong (see Table 1) than what was expected $(48.11 \%+6.49 \%$, or $54.60 \%$ versus $70 \%$ - see Table 1$)$. This is due to the fact that the enrichments of this content were much less numerous than expected $(6.49 \%$ versus $20 \%)$.

The same applies to the uncertainty of the production of meaning in relation to the content of the exhibition. It is lower than expected (9.33\% versus $15 \%)$.

But the expectations regarding the divergence of the production of meaning from the exhibition content $(10 \%)$ are correct. Indeed, direct oppositions (7.43\%) and falsehoods (2.86\%) total 10.29\%.

Finally, the escapes from the subject of the exhibition are much more frequent than expected. Indeed, they are five times more numerous (25. $78 \%$ versus $5 \%$ ).

\section{Discussion}

\subsection{Orientation of visitors' reading}

We have seen that the visitors of this research read only a small portion of the labels, but a large proportion of the panels. How can these data be explained? It is known that the general public visitors come to the museum mainly to see objects and discover their meaning (Dufresne-Tassé and Lefebvre (1996); Dufresne-Tassé, O'Neill, Sauvé and Marin, 2014; Hooper-Greenhill, 1994*). The texts of the labels that closely accompany them physically and intellectually should therefore be of great interest to them, and read in a very high proportion. But in some exhibitions, such as the one chosen in this research, the texts of the labels are usually limited to identifying the objects they accompany, as well as some of their characteristics, such as the materials from which they are made and the time they were created or used. So they present details that remain isolated from each other, i.e. disparate elements located throughout the vast semiological space of an ancient Chinese culture. Such labels therefore have only sporadic and limited interest for a visitor who does not have the knowledge necessary to insert their contents into an organised whole that would make them attractive and give them a real value.

On the other hand, the texts of the panels first present a general description of the subject of the exhibition, then an articulated description of each of the aspects that the exhibition explores. So, for a visitor who knows little about this subject, panels are a much more advantageous source of information than the labels. Therefore, it is not surprising that the visitors of this research read them more than the labels.

However, according to Grassin (2006), the label texts could gain in interest if they dealt with some characteristics of the objects that visitors can observe, and if, at the same time, they systematically detailed the content of a panel devoted to a particular aspect of the exhibition.

\subsection{Visitors' production of meaning}

We just saw that the visitors of this research read panels rather than labels. Because of the articulation between them of the panels, their careful reading allowed the visitors, although they had little or no knowledge of the subject of the exhibition, to develop a structured schematic representation of it. This succinct representation also seems to have led the visitors to deal with the content of the exhibition with very few errors. In addition, it was sufficient for them to associate many elements foreign to the exhibition, elements of course drawn from their personal universe. This association has an important function. It links the content of the exhibition to various elements, memories or ideas of the visitor, and facilitates their integration, retention and subsequent use (Dufresne-Tassé, 2001).

However, the succinct representation acquired by the visitors does not seem to have enabled them to enrich the very content of the exhibition. This is probably because their personal universe did not contain any directly relevant knowledge or experience, so their only appropriate resource was their ability to reason and derive implications from what they observed or read.

Why insisting on the enrichment of the exhibition content? It seems important for two reasons. Firstly, because it establishes a strong link between what the visitor discovers and her/his personal universe. Secondly and probably more importantly, because it contributes to the visitor's immersion in the subject of the exhibition (Dufresne-Tassé, 2014, 2016) and to the appearance of an intellectually and emotionally 
intense but also pleasant experience, which, as stressed by Parker $(2008,2014)$ or Steptoe, Deaton and Stone (2013) contributes greatly to the visitor's psychological and physical well-being.

The accuracy of the interpretation just presented of the reading and meaning production of adults visiting a thematic temporary exhibition will have to be verified during investigations realized in several exhibitions. The huge variation in the characteristics of these exhibitions, but also in the level of knowledge that visitors bring in, should also make it possible to deepen and broaden the interpretation offered here.

\section{References}

Adjadj, J. (2004). Étude du fonctionnement psychologique du visiteur adulte inactif de l'exposition "Edouard Vuillard 1868-1940)". Mémoire de muséologie. Paris: École du Louvre.

Black, G. (2005). The Engaging Museum. Abingdon: Routledge.

Baudon, A. (2002). Étude du public actif de l'exposition "L'Or des Rois Scythes". Mémoire de muséologie. Paris: École du Louvre.

Cabille, E. (2001). Étude sur le fonctionnement psychologique d'un visiteur d'exposition. Monographie de muséologie. Paris: École du Louvre.

Daignault, L. (2011). L'évaluation muséale. Savoirs et Savoir-Faire. Québec, QC: Presses de l'Université du Québec.

Dufresne-Tassé, C. et Lefebvre, A. (1996). Psychologie du visiteur de musée. Contribution à l'éducation des adultes en milieu muséal. Montréal, QC: Éditions Hurtubise HMH.

Dufresne-Tassé, C. (2001). Y si supierammos lo que pensan, imaginan y sentan los visitantes frente a los objetos museales. En S. Singer y H. Ribero-Borel (org.), La pedagogía en el museo: Corrientes actuales (p. 12-32). Mexico: Museo Franz Mayer.

Dufresne-Tassé, C. (2014). Experiencia intensa e experiencia de imersão: Relatório de observações diretas. Museion, Revista do Museu e Arquivo Históerico La Sallem, 19, 27-42.

Dufresne-Tassé, C. (2016). Distinguer une expérience intense courte à propos d'un objet d'art d'une expérience rudimentaire de même longueur. Revue Canadienne de recherches et enjeux en éducation artistique / Canadian Review of Art Education: Research and Issues, 43, 1, 7-16.

Dufresne-Tassé, C., O' Neill, M.C., Sauvé, M. et Marin, D. (2014). Un outil pour connaître de minute en minute l'expérience d'un visiteur adulte. Revista Musologia \& Interdisciplinaridade, 3, 6, 187-204.

Dufresne-Tassé, C., Sauvé, M., Weltzl-Fairchild, A., Banna, N., Lepage, Y. et Dassa, C. (1998 a). Pour des expositions muséales plus éducatives, accéder à l'expérience du visiteur adulte. Développement d'une approche. Canadian Journal of Education, 23, 3, 302-316.

Dufresne-Tassé, C., Sauvé, M., Weltzl-Fairchild, A., Banna, N., Lepage, Y. et Dassa, C. (1998 b). Pour des expositions muséales plus éducatives, accéder à l'expérience du visiteur adulte. Élaboration d'un instrument d'analyse. Canadian Journal of Education, 23, 4, 421-438.

Ericcson, K.A. and Simon, H.A. (1993). Protocol Analysis. Verbal Reports as Data. Cambridge, MA: The MIT Press.

Grassin, A.S. (2006). Observation des objets et lecture des cartels. Le "jonglage" comme stratégie de visite. Le cas de l'exposition "Xi'an, capitale éternelle. Dans C. Dufresne-Tassé (dir.), Familles, écoliers et personnes âgées au musée: Recherche et perspectives / Families, Schoolchildren and Seniors at the Museum: Research and Trends / Familias, escolares y personas de edad en el museo: Investigaciones y perspectivas (p. 177-205). Paris, Conseil international des musées.

Hely, K. (2001). Le fonctionnement psychologique du visiteur en salle d'exposition. Public actif, deuxième partie de l'exposition. Monographie de muséologie. Paris: École du Louvre.

Hirtle, W. (2013). Making Sense out of Meaning. Montréal, QC and Kingston, ON: McGill-Queen's University Press.

Hooper-Greenhill, E. (1994). Museums and their Visitors. London: Routledge.

Jeannoutot, M. (2003). Le fonctionnement psychologique du visiteur inactif pendant la visite de l'exposition "Matisse-Picasso". Mémoire de de muséologie. Paris: École du Louvre.

Krummenaker, C. (2001). "L'exposition Visions du Futur" aux Galeries nationales du Grand Palais, 5 octobre 2000 - $1^{\text {er }}$ janvier 2001: fonctionnement psychologique du visiteur au sein de l'exposition. Monographie de muséologie. Paris: École du Louvre.

Letellier, E. (2003). Étude du fonctionnement psychologique du visiteur adulte appliquée à l'exposition "Matisse-Picasso". Mémoire de Muséologie. Paris: École du Louvre.

Merleau-Ponty, C. et Ezrati, J.J. (2005). L'exposition, théorie et pratique. Paris: L'Harmattan.

Packer, J. (2008). Beyond Learning: Exploring Visitors' Perceptions of the Value and Benefits of Museum Experiences. Curator: The Museum Journal, 51, 1, 33-55. 
Packer, J. (2014). Visitors' Restorative Experiences in Museums and Botanic Gardens Environments. In S. Filep and P. Pearce (Eds.), Touristic Experience and Fulfilment: Insights from Positive Psychology (p. 202-222). London: Routledge.

Poli, M.S. (2002). Le texte au musée: Une approche sémiotique. Paris: L'Harmattan.

Pralus, S.A. (2004). Le fonctionnement psychologique des visiteurs inactifs dans l'exposition "Edouard Vuillard (1968-1940)". Mémoire de muséologie. Paris: École du Louvre.

Quantin, B. (2002). Étude du public actif de l'exposition "L'Or des Rois Scythes". Mémoire de muséologie. Paris: École du Louvre.

Ravelli, L.J. (2006). Museum Texts. Abingdon: Routledge.

Rey-Jouvin, C. (2002). "Le fonctionnement psychologique des visiteurs adultes inactifs. Exposition L'Or des Rois Scythes". Mémoire de muséologie. Paris: École du Louvre.

Rondet, A. (2001). Un public de l'exposition "Visions du Futur": Une approche du fonctionnement psychologique. Monographie de muséologie. Paris : École du Louvre.

Serrell, B. (1996). Exhibit Labels. An Interpretive Approach. Walnut Creek, CA: AltaMira Press.

Steptoe, A., Deaton, A. and Stone A. (2015). Subjective Wellbeing, Health, and Ageing. The Lancet 385, No. 9968, 640-648.

Vicedo, M. (2003). Approche du fonctionnement psychologique du visiteur d'exposition. L'étude du public actif pendant l'exposition "Matisse-Picasso". Mémoire de muséologie. Paris: École du Louvre.

\section{Appendix}

Table 1. Meaning production of 30 adult visitors according to six orientations.

\begin{tabular}{|c|c|c|c|c|c|}
\hline \multicolumn{2}{|c|}{$\begin{array}{l}\text { Meaning corresponds to } \\
\text { content of exhibition } \\
\text { (expected } 70 \% \text { ) }\end{array}$} & $\begin{array}{l}\text { Meaning appears as } \\
\text { uncertain } \\
\text { (expected 15\%) }\end{array}$ & \multicolumn{2}{|c|}{$\begin{array}{l}\text { Meaning diverges from } \\
\text { content of exhibition } \\
\text { (expected } 10 \%) .\end{array}$} & \multirow{2}{*}{$\begin{array}{l}\text { Meaning escapes content } \\
\text { of exhibition } \\
\text { (expected } 5 \% \\
\text { Foreign to } \\
\text { curator } \\
\text { discourse }\end{array}$} \\
\hline $\begin{array}{l}\text { In line with } \\
\text { curator } \\
\text { discourse }\end{array}$ & $\begin{array}{l}\text { Enriches } \\
\text { curator } \\
\text { discourse }\end{array}$ & $\begin{array}{l}\text { Expressed as } \\
\text { question or } \\
\text { hypothesis }\end{array}$ & $\begin{array}{l}\text { Opposes } \\
\text { curator } \\
\text { discourse }\end{array}$ & $\begin{array}{l}\text { Is } \\
\text { notoriously } \\
\text { false }\end{array}$ & \\
\hline Total 4532 & 611 & 879 & 700 & 269 & 2479 \\
\hline Mean $\quad 156.28$ & 21.07 & 30.31 & 24.14 & 9.28 & 85.48 \\
\hline 131.06 & 22.60 & 24.84 & 23.49 & 8.40 & 83.66 \\
\hline 48.11 & 6.49 & 9.33 & 7.43 & 2.86 & 25.78 \\
\hline
\end{tabular}

